\title{
Thorlac Turville-Petre. 2018. Description and Narrative in Middle English Alliterative Poetry. Exeter Medieval Texts and Studies. Liverpool: Liverpool University Press, viii + 222 pp., $£$ 85.00.
}

Ian Cornelius

Loyola University Chicago, icornelius@luc.edu

Follow this and additional works at: https://ecommons.luc.edu/english_facpubs

Part of the English Language and Literature Commons

\section{Recommended Citation}

Cornelius, lan. Thorlac Turville-Petre. 2018. Description and Narrative in Middle English Alliterative Poetry. Exeter Medieval Texts and Studies. Liverpool: Liverpool University Press, viii +222 pp., $£ 85.00$.. Anglia, 137, 3: 488-495, 2019. Retrieved from Loyola eCommons, English: Faculty Publications and Other Works, http://dx.doi.org/10.1515/ang-2019-0043

This Article is brought to you for free and open access by the Faculty Publications and Other Works by Department at Loyola eCommons. It has been accepted for inclusion in English: Faculty Publications and Other Works by an authorized administrator of Loyola eCommons. For more information, please contact ecommons@luc.edu. (c) (1) $(9)$

This work is licensed under a Creative Commons Attribution-Noncommercial-No Derivative Works 3.0 License. (c) DeGruyter, 2019. 
Thorlac Turville-Petre. 2018. Description and Narrative in Middle English Alliterative Poetry. Exeter Medieval Texts and Studies. Liverpool: Liverpool University Press, viii + 222 pp., $f 85.00$.

Reviewed by Ian Cornelius, Loyola University Chicago

E-Mail: icornelius@luc.edu

https://doi.org/10.1515/ang-2019-0043

Thorlac Turville-Petre has produced a vade mecum for readers of Middle English alliterative poetry. The most important poems all receive attention. Two preliminary chapters define the corpus and introduce readers to its language and form. 
The bibliography lists preferred editions. Yet this is not a companion in the sense popularized by Cambridge University Press and Boydell \& Brewer. A new "companion to Middle English alliterative poetry" would be welcome, ${ }^{1}$ but Turville-Petre offers something more interesting: he reads the poems. His subject is poetic technique, especially descriptive technique and the way that descriptions sit within the flow of narrative. Repeatedly and patiently, he directs readers' attention to "characteristic specificity" (161) and "particularising detail" (180), and to the ways that poets crafted "passages of vivid description" from their "extraordinary rich verbal resources" (37). In an initial illustration, he examines the description of Alexander's flesh-eating horse Bucephalus in The Wars of Alexander, comparing that with the corresponding passage in The Prose Life of Alexander (20-22). The Cleanness-poet's description of the holy vessels of the Temple, and of Belshazzar's sacrilegious misuse of them, run through this book as its leitmotif (8, 48-49, 83, 92-93, 104, 122).

The basic unit of analysis is the "set-piece description" (38), not the poem. A chapter on Sir Gawain and the Green Knight examines descriptions of Gawain's shield, the Green Knight, the castle at Hautdesert, and the Green Chapel, concluding that "[t]he description of the Green Chapel is the most striking and effective example of a set-piece description in the poem, indeed anywhere in Middle English literature" (54). Later chapters read Arthur's dreams and the giant of Mont Saint Michel in Morte Arthure; the civic ceremony attending Alexander's entry into Jerusalem in The Wars of Alexander; mysterious artifacts in St. Erkenwald; gardens and landscapes in A Pistel of Susan and Mum and the Soothsegger; military sieges in The Wars of Alexander and The Siege of Jerusalem; and the sea storms and floods of Patience, Cleanness, and The Destruction of Troy. Scenes from The Awntyrs off Arthure, Piers Plowman, and Pierce the Ploughman's Crede receive briefer treatment. Readings are deepened and pointed by strategic comparison with non-alliterative works: Richard Maidstone's verse account of Richard II's ceremonial entry into London in 1392 (81-85), John Page's harrowing verse account of the siege of Rouen (162-165), and scenes from classical Latin poetry, especially Virgil's Georgics and Aeneid and Ovid's Metamorphoses.

In the introduction Turville-Petre announces three claims. The first is that, contrary to "prevailing opinion", Middle English alliterative poetry is usefully construed as "a tradition" (2). The second, that "the influence of classical writers has been underrated" and that "Virgil and Ovid in particular" were models for the "descriptive techniques" of the Middle English alliterative poets (18). The third, that the poets wrote from "their own experience of scenes and events", not just

1 The incumbent in this genre is Lawton (1982). 
prior literary tradition (18). This review aims to unpack the first two of these claims. For the third, see especially pages 51-52, 103, 112-114, 202-203. It is argued persuasively.

Regarding the first claim, much depends on definitions of 'tradition': does one mean that the poems are products of a traditional craft (analogous to traditional crafts of ship-building, for example), or that they are linked in a web of intertextual borrowing and allusion (analogous to the tradition of Latin poetry after Virgil, or of the Chaucerian tradition in the fifteenth century)? Turville-Petre begins in the first position. His statement that "it is principally the metre and vocabulary that distinguishes alliterative poetry from that written in other traditions” (4) remains vulnerable to James Simpson's skeptical riposte that “deployment of an alliterative metre [does not] constitute a 'tradition' in any but the weakest sense" (quoted at 2 n. 2).

Yet the argument about tradition does not end there. The two senses of tradition are related, in that a shared and formulaic (that is, traditional) poetic language, distinctive of alliterative verse, frustrates efforts to identify specific instances of textual borrowing. Does a verbal collocation shared by two poems indicate borrowing, or only common recourse to a shared wordhoard? If a tradition in the strong sense is considered implausible or undemonstrable in connection to alliterative verse, the weak sense may appear merely uninteresting. Literary scholarship has recently been more interested in diagnosing the cultural meanings of literature than in engaging in literary language as such, and more interested in contexts of reception than in practices of composition. (Simpson once instructed this reviewer to "write about ideology".) By his focus on literary language and poetic craft, Turville-Petre returns to the critical priorities of an earlier era. A. C. Spearing's work is saluted, and Turville-Petre's reading of the Green Knight's entry into Camelot resonates with Marie Borroff's fuller account of the same scene (42-45; cf. Borroff 1962: 110-120). Turville-Petre is not uninterested in ideology: he argues trenchantly that critics are wrong to find "a condemnation of Arthur's wars of aggression" in the Morte Arthure (75; see also 153, n. 22). Yet even that argument is conducted through shrewd philological observation. As Turville-Petre points out, a key line, adduced as evidence of the poet's condemnation of Arthur, is patently corrupt in the single manuscript witness to the poem (76). A perception like that is possible only if one takes seriously the implications of a literary tradition, in the weak sense of a fons of expressive possibility.

Moreover, though Turville-Petre does not say so in the introduction, this book advances an argument that several of the Middle English alliterative poems are linked into a tradition in the stronger sense, through a network of textual borrowings. On the basis of similarities in phrasing, Turville-Petre holds that "the Pearl- 
poet probably knew" The Wars of Alexander (125), that the author of The Siege of Jerusalem probably knew the Pearl-poet (177), and that John Clerk drew from The Siege of Jerusalem in his Destruction of Troy (149 n. 17, 174 n. 19, 176-177). Clerk's dependence on The Siege of Jerusalem was argued, cautiously, by Hanna and Lawton (2003: xxxv-xxxvii), but Turville-Petre's identifications go further and they are notably bullish. In a recent edition of the Cotton Nero poems, Putter and Stokes (2014) remark on some of the relevant passages, but claim no special significance for shared language. Similarly, Turville-Petre and Hoyt N. Duggan concluded in an agnostic mode in their edition of The Wars of Alexander:

It is likely enough that two poets writing in approximately the same part of the country and within the same stylistic tradition would have known one another's work, and entirely probable that one writer would have drawn on the other. Unfortunately, there is no way of determining who was the borrower and who the lender. (Duggan and Turville-Petre 1989: xliii)

Turville-Petre now adds to the list of parallel passages and holds Wars to be the lender. The decisive factor is the gilt and gem-studded arboreal landscapes described in Wars and Pearl: the description in Wars derives from the Latin source of that poem, whereas the "blue trunks and silver leaves" in Pearl are a departure from "traditional accounts of the Earthly Paradise" (124-125). From this, TurvillePetre reasons that any borrowing is likely from Wars to Pearl. More discussion would have been welcome. If accepted, this argument will establish a new terminus ad quem for the composition of Wars; it may also yield interesting intertextual readings of the Green Knight/Bertilak. ${ }^{2}$

Leaving the relation between Wars and the Cotton Nero poems to one side, the remainder of Turville-Petre's conjectured sequence is of interest because it joins his argument about alliterative tradition with his argument about classical sources. Patience, The Siege of Jerusalem and The Destruction of Troy each contain set-piece descriptions of ships engulfed by storms at sea. The relevant scenes in The Destruction of Troy, probably the latest of the English poems under consideration here, derive from Clerk's Latin prose source, Guido delle Colonne's Historia destructionis Troiae, but the scenes in Patience and Siege require another explanation. In the chronology posited by Turville-Petre, Patience contains "the earliest sea-storm in alliterative poetry" (177; more correctly, the first after Lawman's Brut). Similar descriptions appear in Latin poetry, where they are a recognized topos. Readers have wondered whether the English poets knew the Latin poems, and Turville-Petre argues that the Cotton Nero poet probably did. For his sea-

2 See the parallel passages listed at Duggan and Turville-Petre (1989: xliii). 
storm in Patience, he probably drew on instances of the topos in Latin poetry, probably the Aeneid or Metamorphoses (177-180), while Latin biblical poetry probably stands behind the Flood in Cleanness (188-189). These arguments build on Jacobs (1972) and Putter (1997). ${ }^{3}$ Turville-Petre also compares the rural and apiary descriptions of Mum and the Soothsegger with those in Virgil's Georgics (132-137). There the poet's acknowledged source is the thirteenth-century prose encyclopedia De proprietatibus rerum, which is sufficient to supply the details of the poet's bee-keeping allegory. Turville-Petre places the poet's debt to Virgil at a deeper level: not for the details themselves but for their "significance in the poem" (136).

In the introduction to an important collection of essays on Middle English alliterative poetry, David A. Lawton indicated the omission from that volume of an essay on "the medieval Latin background" to this poetry (Lawton 1982: 15). Turville-Petre moves this research area forward by showing how Virgil and Ovid could have taught the alliterative poets their descriptive technique. Precise source identifications will remain elusive, as Putter (2010: 171) remarks in a related context. Turville-Petre doubts that alliterative poets were indebted to the twelfthand thirteenth-century artes poetriae (15-18, 200), and that seems right, but the field of possible models remains large; recent studies of Latin language pedagogy and vernacular poetics have shifted focus away from the famous manuals, attending instead to a wider range of teaching materials preserved in English school books of the thirteenth, fourteenth, and fifteenth centuries. In this connection, Piers Plowman and recent scholarship on it may deserve more prolonged attention than this book accords to them. Langland is unique in making the schools a central theme of his poem, but other alliterative poets underwent similar programs of grammatical instruction, where they may have first encountered the Latin poetry posited in Turville-Petre's argument. (The line of inquiry is acknowledged but not pursued: see 136 and n. 34). Turville-Petre's remarks on Langland's descriptive technique are precise and authoritative, but limited in ambition: he reaffirms Langland's well-known stylistic differences from the alliterative poets of the "high style" (26-29, 148-149). His argument about Latin influences invites readers to consider anew Langland's evident lack of engagement with Roman poetry. ${ }^{4}$

3 See also Putter and Stokes (2014: 580), note on 1l. 129-156.

4 Robert Costomires claims that Langland's Hunger derives from the myth of Erysichthon as told in Ovid's Metamorphoses, but Costomires is not able to identify specific textual echoes and does not consider a more likely source, the portrait of Faim in Jean de Meun's Roman de la Rose. See Costomires (2014); compare Barney (1995: 8-9). 
Similarly, Turville-Petre's claims for verbal borrowing within the corpus of northerly alliterative poems should be considered in connection with the "Piers Plowman tradition", a grouping that has seemed secure. Wendy Scase rehearses the evidence of verbal borrowing among these poems and draws the connection to Latin literary pedagogy: "Just as schoolboys were taught to imitate their textbook models when composing on themes set by their schoolmaster, along the lines of Proba, Juvencus, Avitus, Sedulius, and Arator", she writes, "so the Pierstradition poets characteristically borrow fragments of Piers and redeploy them to develop their own distinctive themes" (Scase 2013: 42). Turville-Petre's evidence of a Wars of Alexander-tradition is, of course, slender and equivocal by comparison.

In a final chapter, Turville-Petre briefly examines Lawman's Brut, concluding that the later alliterative poets do not owe their descriptive technique to that poem. The conclusion is surely correct, but Lawman remains relevant. In a fundamental study, Elizabeth Salter (1988: 61-66) argued that the extended similes in the Arthurian section of the Brut are probably inspired by Latin epic. Turville-Petre reports Salter's opinion with approval but misses an opportunity to extend the state of play. Taking the arguments of Salter and Turville-Petre together, it seems that Lawman and the fourteenth-century alliterative poets were both indebted to Latin poetry for elements of their descriptive technique, though differently: Lawman for extended similes, the later poets for set-piece description.

Turville-Petre compares the "rhythmic flexibility" of the Middle English alliterative line to "the fluidity and spaciousness of the Latin hexameter" (172, 202). In a similar vein, Traugott Lawler has compared the line-ending rhythms of Latin dactylic hexameter with those of Middle English alliterative verse (Lawler 2011: 62). As these scholars recognize, the analogy only runs so far. The caesura in the Latin meter is entirely unlike the homonymous mid-line division in the English meter. Middle English alliterative verse tends towards stichic composition, again unlike classical Latin hexameters.

I would have preferred to read the section on "The Potential of the Form" (141-147) earlier in the book, where it might have informed subsequent exposition of the poetry. Turville-Petre has interesting things to say about "phonaesthemes" (145) and sound effects. His patient unpacking of verse construction (e.g., 181, 190) occasionally shows that his understanding of the meter differs from the studies he cites on this subject. Elaboration of differences might have been productive. The constructed verse Pe wyndes on pe water expresses the standard pattern of alliteration in the a-verse (this is Turville-Petre's point, 181), and has the syntax of an a-verse, but its rhythmical contour (xSxxxSx) is characteristic of the b-verse. In the a-verse one would expect a long initial dip, a non-schwa vowel in the final dip, or an additional lift-bearing element. Where Turville-Petre speaks 
of "positions" on the same page, I would prefer "lifts" or "strong positions": hence a "two-lift norm" rather than a "two-position norm".

Description and Narrative in Middle English Alliterative Poetry is the happy product of long and industrious study of this poetry. Much of Turville-Petre's previous work has been devoted to the more technical aspects of literary scholarship: documentary witnesses and their scribes, prosopography, local history, textual criticism, and editing. ${ }^{5}$ In this book he treats such topics with a light touch. Reviewers of Turville-Petre's previous book-length study of Middle English alliterative poetry (Turville-Petre 1977) objected to his treatment of this poetry as a distinct mode, set apart from other contemporary literary production. The objection may be raised against Description and Narrative, too, but it meets this book at an oblique angle, not as a frontal engagement with the author's aims. One wants to understand this poetry in the context of its production and circulation in fourteenth- and fifteenth-century England. One may also want to read this poetry in the context of Weltliteratur. By his focus on poetics, literary traditions, and the responsiveness of poets to historical particularities of their experience (a theme omitted in this review), Turville-Petre invites readers to engage the Middle English alliterative poems as communicating across the differences of time, culture, and language. He invites us to read the poems as having something interesting to say to us - or, if not that, as having an interesting way of saying things.

\section{Works Cited}

Barney, Stephen A. 1995. “A Response to John A. Alford's 'Langland's Learning”. Yearbook of Langland Studies 9: 8-10.

Borroff, Marie. 1962. "Sir Gawain and the Green Knight": A Stylistic and Metrical Study. New Haven, CT: Yale University Press.

Burrow, John A. and Hoyt N. Duggan (eds.). 2010. Medieval Alliterative Poetry: Essays in Honour of Thorlac Turville-Petre. Dublin: Four Courts Press.

Costomires, Robert. 2014. "Langland Reads Ovid: The Myth of Erysichthon and the Figure of Hunger in Piers Plowman". The Mediæval Journal 4: 71-90.

Duggan, Hoyt N. and Thorlac Turville-Petre (eds.). 1989. The Wars of Alexander. EETS SS 10. Oxford: Oxford University Press.

Hanna, Ralph and David Lawton (eds.). 2003. The Siege of Jerusalem. EETS OS 320. Oxford: Oxford University Press.

Jacobs, Nicolas. 1972. “Alliterative Storms: A Topos in Middle English”. Speculum 47: 695-719. Lawler, Traugott. 2011. “Langland Versificator”. The Yearbook of Langland Studies 25: 37-76.

5 A list of his publications to 2008 is printed by Burrow and Duggan (2010: 15-18). 
Lawton, David A. (ed.). 1982. Middle English Alliterative Poetry and Its Literary Background: Seven Essays. Cambridge: Brewer.

Putter, Ad. 1997. "Sources and Backgrounds for Descriptions of the Flood in Medieval and Renaissance Literature”. Studies in Philology 94: 137-59.

Putter, Ad. 2010. "Cleanness and the Tradition of Biblical Versification”. In: John A. Burrow and Hoyt N. Duggan (eds.). Medieval Alliterative Poetry: Essays in Honour of Thorlac TurvillePetre. Dublin: Four Courts Press. 166-84.

Putter, Ad and Myra Stokes (eds.). 2014. The Works of the Gawain Poet: Sir Gawain and the Green Knight, Pearl, Cleanness, Patience. New York: Penguin Books.

Salter, Elizabeth. 1988. English and International: Studies in Literature, Art and Patronage of Medieval England. Ed. by Derek Pearsall and Nicolette Zeeman. Cambridge: Cambridge University Press.

Scase, Wendy. 2013. "Latin Composition Lessons, Piers Plowman, and the Piers Plowman Tradition”. In: Frank Grady and Andrew Galloway (eds.). Answerable Style: The Idea of the Literary in Medieval England. Columbus, $\mathrm{OH}$ : The Ohio State University Press. 34-53.

Turville-Petre, Thorlac. 1977. The Alliterative Revival. Cambridge: Brewer. 